\title{
Reviewing the Final Function of the Disciplinary Institution of Shurta (Police) during Shiite Buyids Government Dominance on Baghdad
}

\author{
Haitham Shirkosh ${ }^{1}$, Asghar Mahmoudabady ${ }^{1} \&$ Asghar Forughi $^{1}$ \\ ${ }^{1}$ Department of History (History of Islam), School of Literature Humanities, University of Isfahan, Isfahan, Iran \\ Correspondence: Haitham Shirkosh, Department of History, School of Literature Humanities, University of \\ Isfahan, Hezarjarib St., Isfahan, Iran. Tel: 98-913-214-2740. E-mail: shirkosh.haitham@yahoo.com
}

Received: September 4, 2012

Accepted: November 18, 2012 Online Published: March 22, 2013

doi:10.5539/ach.v5n2p66

URL: http://dx.doi.org/10.5539/ach.v5n2p66

\begin{abstract}
During Abbasid Dynasty, Shurta Institution (Police) was one of the disciplinary and security systems whose duty was establishing order and security as well as fighting against the corrupt people and criminals i.e. Ayyaran. During the third period of Abbasid dynasty, which is known as Buyids era, the institution of Shurta experienced a number of changes in comparison with the first Abbasids periods, some of which were. the direct interference of the governors of buyids in appointing Sahib Al-Shurta (Shurta administrator), paying the guaranty fee of this job to the treasury of Buyids in order to accept those jobs by those who were appointed to do so, and also political considerations in appointing Sahib Al-Shurta. In addition, at the end of the dominance of Buyids on caliphate of Abbasids and the beginning of their decline, another period of caliph's interference was observed in appointing the administrators of the Shurta of Baghdad. This paper is aims at to study and analyze the function of this institution during the period of Buyids dominance on Caliphate of Abbasids in Baghdad (955-1068) and some of its consequences, as well as dealing with security circumstances of that period.
\end{abstract}

Keywords: Shurta, Abbasids, Buyids, Ayyaran, Sahib Al-Shurta

\section{Introduction}

The institution of Shurta is one of the first and most important organizations of the Islamic civilization so as to make social security and fighting against the representations of corruption and disorder all along the history of its existence.

The term Shurta which is derived from the root sh-r-t, is one of the terms related to the Islamic government. Regarding the meaning of this word's root, it has been referred to the special and elite units whose duty was executing the rules and law enforcement. Sahib Al-Shurta is a term which refers to the commanders of this institution (a group of authors, 1997, p. 510).

The commands of Imam Ali to Ma'lik AL-Ashtarthe i.e. the administrator of Egypt, indicated that the establishment of this institution at least goes back to the Caliphs of early Islam. Furthermore, the disciplinary nature of Shurta which is in line with guarding the social security is also visible in this command (Al-Sharif Al-Radi', p. 349).

Apparently, this institution was gradually organized during Imam Ali and the periods of Umayyad and Abbasids. This organization became so important in Abbasid era so that Abu Jafar AL-Mansu'r, the second Abbasid Caliph, considered Shurta as one of the four principles of the government including Qa'di, Sahib Al-Khabar (someone who is in charge of collecting information and news), and Sahib Al-Khara'j (someone who is in charge of collecting taxes). He also considered major prerequisites of innocence and continence for this position (Tabari, 1967, p. 67).

Despite the importance of Shurta institution in Islamic history, historical reports and subjects about this institution are inconsiderable, and some historians just mentianed the name of Ashab Al-shurta (Shurta administrators), and among these historians, only Ibn Khaldun's famous book i.e. Al-Moghadama, possesses a chapter devoted to Shurta institution which has been stated very briefly and there were no answers to uncertainties and questions about Shurta. 
Except Ibn Khaldun, authors such as "Abu Al-Husain Ishaq Ibn Ibrahim Al-Katib" in his book Al-Borhan fi Vojuh Al-Bayan" and "Ahmad Ibn Abi Rabi'a" in his book "Solouk Al-Moluk fi Tadbir Al-Mamalik" just have described characteristics of Sahib Al-Shurta.

In recent literatures, the term Shurta is briefly noted in The Encyclopedia of Islam and it has not explained its circumstances in various historical periods separately.

However, due to the lake of historical documents and literatures concerning the Shurta, researchers often have encountered comprehensive analysis of articles, literary narratives and stories to achieve some facts about this institution.

Given to the above mentioned issues, obtaining precise points of Shurta in different eras has been faced with difficulties and this paper evaluats the performance of this institution in Buyids period in Baghdad.

\subsection{The Functions of Shurta of Baghdad during Buyids Period}

Through studying the historical evidence, it is revealed that the most important functions of Shurta were counteracting with the law breakers and people led astray, chasing the evil and corrupt people, executing the verdicts and Hudu'd (the Islamic sentences), administrating the prisons, fighting with the evil acts and representations of evil acts and oppressions, establishing security of roads and caravans, 24-hour guarding the passages, and chasing the robbers and escaped criminals. In his governmental command to Fakhr AL-Dawla AL-Deylami (976-997) the Caliph AL-Tai' (973-991) communicated all of the above mentioned items and emphasized that the ones appointed to this position must have been selected from the pious and God-fearing people (Qalqashandi, 1916, p. 39).

At the same time, in a similar command to Yu'suf Ibn-Tashefin (1070-1106), the Amir (Governor) of Andalusia and Moroccan regions, Caliph Al-Qa'im (1030-1074) added a number of functions such as executing the orders of the judicial authorities including recalling and arresting the suspects and guilty people, maintaining the order of the courts, and also supporting the representatives of the government in collecting the taxes from the assigned districts (Ibid, pp. 31-39).

The two above mentioned commands demonstrated a great deal of similarities between the functions of Shurta in that period and that of the contemporary disciplinary institutions as well as the similarity of the Shurta duties in all of the regions under the dominance of Abbasids.

It should be accepted that all of the mentioned functions accompanied danger and problems, and it was more serious in the capital of Abbasids because like the other great and populated capital cities of the world, people of different races, social classes, and nations used to live there. Therefore, a strong Shurta and skilled Sahib al-Shurta were among the major requirements of the capital city of Abbasids.

During Abbasids period, Baghdad was divided into a number of districts and regions each called "AL-RUB' i.e. QUARTER, (Tanu'khi, 1995, p. 231). The Sahib al-Shurta had a representative in each of these district who was referred to as Sahib al-Rub' (administrator of the quarter) whose function was to provide the Sahib al-Shurta with appropriate reports about the security affairs (Qalqashandi, 1916, p. 351).

The written reports of the Shurta forces to the commanders and administrators were called Riqa' the plural form of the term Roq'a (Tanu'khi, 1985, p. 273). In order to collect information and news and tracking the criminals and detecting their ambushes, the officers of Shurta got help from Uyu'n and the spies. In this regard, Masu'di quoted from a group of penitent robbers: “Tawwa'bi'n (penitent robbers) were the old robbers who were disabled and repented and whenever a robbery took place they were aware of the persons in charge and would reveal their place" (Masu'di, 1409, p. 160). Apparently, for their cooperation and providing the source of news as a spy, they received 10 Dinars a month (Ibid, p.161).

\subsection{The Groups of Criminals and Evils during Buyids Period in Baghdad}

During that period in Baghdad, there were a number of people who used a hanged knife on their waist and used it in their struggles. These people were known as As'ha'b Al-Saka'kin and make the society insecure and corrupted. During the government of Muizz Al-Dawla AL-Deylami (932-966), the group of criminals and Asha'b Al-Saka'kin were very active and made the entire city insecure. Abu Mohammad AL-Muhallabi, the deputy of Muizz al-dawla, ordered to arrest all the criminals and their gangs and also to banish a number of authorities who had misused such evil people in achieving their goals. Through such measures, he put an end to the mentioned seditions (Tanu'khi, 1995, pp. 86-87).

In another case, AL-Muhallabi banished a group of As'ha'b Al-Saka'kin and criminals to one of the regions of Ahwaz by covering boats in order not to let them escape (Ibid, p.144). As a deputy, he used to gather people who 
pretended to be Sufi and A'rif (Mystics) and uttered indecent words and made people astray. In such gatherings, in order to convince them, he discussed with them in presence of the judges, jurisprudents, and Sahib al-Shurta. They were punished and were banned to hold any meeting, if necessary (ibid, p. 145). As it seems, the fake mysticisms were one of the major security problems so as to make the authorities react in such way.

Furthermore, in that time, about 60 sects and groups of robbers were detected, each of which had their own techniques in robbery. One of these groups was Tarra'ra'n who were skilled in stealing others' properties in a secret way and also Ashab Al-Fosu's who was the name of another group whose technique was carving the name of people on the ring gem and then went to their family to get some properties and carried used that ring as the proof that the owner of the properties is aware of this (Hamada'ni, 1923, p. 207). Some of these robbers acted in appearance of the Shurta and their organizational weapon. This group was called As'ha'b Al-Tabarzi'n (Tabarzi'n was a small axe which was the organizational weapon of Shurta of that period) (ibid, p. 211).

The occurrence of the fourth and fifth centuries was accompanied by Ay'yaran, the urban riotous people whose disturbances and seditions are mentioned repeatedly in historical texts including AL-Muntadam of Ibn AL-JAwzi and Al-Ka'mil of Ibn Athir. In these two centuries, the Ayyaran group was very active and even the governors asked for their assistance in conflicts and struggles. For instance, Abu Jafar Shi'rza'd who fought with Muizz Al-Dawla AL-Deylami on behalf of Nasir Al-Dawla Hamda'ni, asked for help from Ayyaran (Moskovayh, 2000, p. 123).

Given to the reports of Ayyaran in another scene between Ami'n and Mamun in Baghdad, it seems that Ayyaran were emerged in the period of Izz Al-Dawla Bakhtia'r and each of them became dominant in one of the districts of the city and started to attack other neighborhoods (ibid, p. 374).

The major activity of Ayyaran in that period was sparking conflicts among those neighborhoods with excuses which were sometimes religious and to get the most out of it to murder people and steal their properties.

Such groups of Ayyaran, sometimes participatted in assassinating the Sahib Al-Shurta (Ibn AL-Jawzi, 1992, p. 233) and also by sending massages requested for ousting the Sahib Al-Shurta with which they had kind of problem (ibid, p. 245). In some cases, for years they made it impossible for the pilgrims from Iraq and Khura'sa'n to go to Mecca for Hajj. They also expelled the Shurta forces from the city (Ibn Kathir, 1986, pp. 19\&39).

In that period, there were public houses (cabaret) and corruption centers and some of the owners of these centers used to pay monthly to one of the authorities to let them act freely. In this regard, Tanu'khi mentioned someone named Ibn AL-Harra'sa who paid two thousand Dirhams to one of the Deylami commanders named Shi'rmardi to have his support. Therefore, no one caused a problem for him in fear of the Deylami commander and he was free to do any kind of evil acts in his house. Even robbers were hidden in his house. The news of this house spread so much that Muizz AL-Dawla AL-Deylami heard that and ordered his forces to attack that house and scatter the inhabitants (Tanoukhi, 1995, pp. 349-350).

\subsection{The Religious Conflicts during Buyids Period in Baghdad}

Among all these measures, the religious conflicts and their negative impacts on the security of this period should be taken into consideration. It seems that such conflicts were as serious in other times as in the fourth and fifth centuries. It should be noted that although the governors of Buyids strengthened the Sunni Caliphate of Abbasids, for the first time in the history of Islam, a Shiite governor took the power, and consequently, this was a difficult situation for both the Sunni Caliph and the Shiite Governor who believed that they usurped the Caliphate and prevented the process of ousting them only for the political considerations. On the other hand, for the first time, the Caliph and the Governor were at the same place i.e. Baghdad (Ibn AL-Jawzi, 1992, p.45). This incident as well as the deep religious gap between these two immediately caused a number of influences on the superior position of Buyids and enhancement of the Shiite position.

For the first time, in Ashu'ra' in 963, the ceremony for Imam Husain was held by closing the stores under the order of Muizz Al-Dawla (Ibn Athi'r, 1965, p.549) and also a celebration was held in anniversary of Ghadi'r Al-Khom (ibid, p. 550).

In terms of social classes, because of Shiite avoidance of Taqyyia and having the support of the power of the Shiite governor, a number of structural reforms took place including establishr pt of the Shiite cities and townships like Karkh in Bagdad (Khati'b Baghdadi, 1931, p. 81). Since then, every year during Muharram and Ghadir, some riots and conflicts have taken place between the Shiite and Sunni people and a number of each group have been killed. By arrival of Ayyaran and evil people, such conflicts and gaps between the two groups entered a new phase. 


\subsection{The Methods of Forcing Criminals for to Confess During Buyids Period}

In this period, the Sahib Al-Shurta used to use special methods to make the criminals to confess. Abu AL-Hasan Abza' Ajji was the Sahib al-Shurta of Muizz AL-Dawla government who was extremely strict. He had a special way to make the criminals and guilty people confess. He made the criminal stand between two guys and a number of Shurta forces standing behind him. Whenever he scratched his head, they suddenly gave the criminal a lash on his back. Sahib Al-Shurta pretended to be angry with the Shurta who gave the lash and told him: "God may cut your hands and legs! Who let you hit him?" then he turned to the criminal and said: "don't worry! Tell the truth to get free. If you confess, it won't happen again!" If the man did not confess, he would scratch his head again and this would continue until the criminal confess whatever he did (Tannu'khi, 1995, p. 217). This method demonstrated that the methods of making criminals confess were simple and at the same time very cruel and there was possibility of judging mistakenly. There might even be cases in which someone confessed something that he did not actually do or someone died under the pressure of the tortures.

In other periods of Abbasid era, other methods were used. One of these methods which was mentioned by Masu'di in a report of Caliph AL-Mutadid period, was allowing those guilty people not to sleep in order to force them to confess (Masu'di, 1409 A.H., p.162).

\subsection{The Punishments of the Thieves during Buyids Period in Baghdad}

Due to the frequency of robbery during this period, the robbers' punishment was burdensome. In the time of Muez Al-Dowla Deylami, Abulhasan Abza Ajji, the Sahib Al-Shurta in Bagdad, used to get Muez Al-Dowlas permission for punishment of the robbers and then, in the afternoon, took the robbers out of the jail and hung them up and later in the next morning they cut their head off (ibid, p. 214). It seems that such executions were in the force major cases and without any trial and just by the order of the Buyids governors and were performed to prevent the wide spread robberies which endangered the social security.

Apparently in that time, it was not common to hang the guilty ones, they hung the guilty person from hands and shoulders. Therefore, they would suffer very much until their heads were cut by them.

Moskovayh reported that in the periods when robbery became very common, whenever they would arrest a robber, people would kill him before he could be taken to the governor on trial (Moskovayh, 2000, p. 113). In some cases, they kept the robbers in jail to let people get rid of them. In such cases, they paid for their costs and clothes from Bayt Al-Ma'l (the Treasury of Muslims) and sometimes because no budget was allocated for the prisoners, it caused them to get Sadaqa (the charity) from people while they were hung with chains (Abu Yu'sof, 1979, p. 150).

In one of his accounts, Ibn AL-Jawzi reported that in 1036, the group of Ayyaran attacked one of the prisons of Baghdad and killed a number of Shurta forces (Ibn Jawzi, 1992, p. 256). This story demonstrated that administration of the prisons was one of the responsibilities of Shurta.

By arrivial of Adod Al-Dowla AL- Deylami to Baghdad (977-982), a number of measures were taken in order to counteract the robbers. The time he entered into Baghdad, all roads of this city were insecure and brigands were everywhere in the roads stealing people's properties. He sent an army to attack Bani Shayba'n, the tribe which was in charge of most of the disorders and insecurities. The army assassinated most of them and arrested 8,000 of them. One of the other measures of Adod Al-Dawla in counteracting the brigands was to make the tribes -who were active brigands- reside in a land between Fars and Kerman to start agriculture (ibid). This measure, indeed, limited the rate of crime and rehabilitated the criminals and consequently reduced the extra costs for the treasury of Buyids.

After Adod Al-Dawla, robbery became common again and the situation became so terrible that robbers used to steal form the government palace in Baghdad in 1030. Afterwards, a number of 24-hours guards were appointed to guard the palace (ibid, p. 213). In this case, it is worth mentioning that the corruption of some of the administrators and commanders of the army made the robbery more widespread and the robbers more insolent. This was also the case even before the dominance of Buyids on Baghdad.

In this regard Moskovayh reported that there was a robber in Bagdad named Ibn Hamdi who made the administrators angry. Ibn Shirza'd, one of the commanders of caliph army, compromised with him and signed a contract in which Ibn Hamdi and his gang were obliged to pay 15,000 Dinars of the robbed properties each month to Ibn Shirza'd and take a receipt for it. Therefore, having signed this contract, the mentioned robber became more active and started to rob people's properties and made people really angry and obsessed. Eventually, Abu AL-Abba's Eshkovarj Deylami, the Sahib Al-Shurta of Bagdad arrested him in 332 and executed him (Moskovayh, 2000, pp. 83 \&89). 


\subsection{Interference of Military Authorities in Establishment of Order and Security in Baghdad}

In the period of Buyids government, the situation became so serious and people got so unsatisfied with the disorder made by Ayyaran and inefficiency of Shurta in controlling the situation of Baghdadthat Baha AL-Dawla Deylami (989-1012) decided to send Abu-Ali Ibn Usta'd Hurmoz who was the Amid Al-Joyu'sh (Commander of the Army) to Iraq to bring back the order and security to Baghdad. In his set of actions, he prevented the Shiite and Sunni from holding FROM religious rituals and tied Shiite and Abbasid Ayyarin together two by two and drowned them in the river. He also banished Ibn AL-Mu'allim the great Shiite Jurisprudence and ordered to residents of Karkh and Ba'buttaq who were Shiite not to hold the ceremonies related to A'shu'ra's day (Ibn AL-Jawzi, 1992, pp. 33\&37).

However, such measures had very limited and transient effect as if the riots, disorders, and insecurities started over. This fact made it possible for the Abbasid Caliph to be freer from interfering directly in selection and appointment of the disciplinary authorities. Accordingly, in 1030, the Caliph Al-Qadir appointed his Ha'jib, Abu Mohammad Nasa'wi, to the position of Sahib al-Ma'oonah (one of the equivalences of the term Sahib al-shurta which emerged in the late third century). More interestingly was that he appointed a number of the members of Ayyaran as the assistants and forces under his authority (ibid, p. 207). Consequently, the employment of Ayyaran in the institution of Shurta had negative effects and the reason of Ibn Nasawi success in putting an end to the riots was due to this fact. Ibn Nasawi, himself was accused of murder and robbery later and got imprisoned for that (ibid, p. 305).

Moreover the caliphate system asked for help from the Shiite religious authorities to find a way to verify the disordered affairs. For instance, in 1033, AL-Sharif AL-Murtada was asked to invite Ayyaran to his house, make them repent, suggested that they can be employed in institution of Shurta, and even gave the ones -who were ready to leave the city- a three-day opportunity (ibid, p. 242). But apparently the riots and seditions continued and in a line of religious conflicts, the angry Sunnis ruined the holy shrine of Ka'zemayn near BagHdad and did not respect the tombs of the dead of buyids. Adna'n Ibn Sharif Radi, the Naghi'b (leader) of Shiite people could prevent them from disrespecting the bodies of Shiite Imams (Ibn Athir, 1965, p. 577; Ibn AL-Jawzi, 1992, p.331).

In 1055, the sedition led in the conflict between Hana'bela and Asha'era (Ibn Athir, 1965, p. 614). The caliph Al-Qa'em was also unsuccessful in finishing the disordered situation and establishing order and security. The Sahib Al-Shurta also could not retrieve the disordered situation and this condition continued until the entrance of Toghrol Beik Selju'ki to Baghdad (Ibn AL-Jawzi, 1992, p. 347).

However, counteracting the riots of Ayyaran and religious seditions was one of the major preoccupations of Shurta in that period.

\subsection{Appointment of the Sahib al-Shurta for Baghdad}

After dominance of Buyids in Baghdad, their attempts to seize the governmental structures of Abbasids increased, the responsibilities of the Caliph limited and his ideas were ignored in appointment and ousting of the judges and administrators of other occupations.

Biru'ni considered the dominance of Buyids a fundamental change in the caliphate affairs. He adds: "the governments transferred to Buyids in late period of Muttaqi and early period of Mustakfi, the two Abbasids Caliph" (Biruni, 1984, p.203).

The institution of Shurta was also affected by this transfer. On the one hand, in the period of Muizz AL-Dawla, some of the governmental positions were appointed to some people in return for amounts of money received as bribe. The report of Moskovayh directly mentions the process of appointing someone to the position of Sahib Al-Shurta in return for receiving 20,000 Dirhams per month (Muskovayh, 2000, p. 231). It seem that this was with the intention of earning more money in the time of reduction of taxes received and earnings of the government because of the draught and catastrophes like that and maybe this act was kind of taxpaying to the treasury of Buyids for the earnings of the Shurta through registering the claims and investigating them which is referred to as Tadmin (guarantee) by Ibn Athi'r (Ibn Athi'r, 1965, p. 537).

Accordingly, in appointing people to this position, the matter of political supports and agreements in attitudes was of high importance. The account of Ibn Moskovayh of Khamma'r, the Sahib Al-Shurta of the period of AL-Muti, the Abbasid Caliphate (945-973) was a confirmation of this claim. It seems that Khamma'r was one of Izz al-Dawla's close friends; because in the account mentioned above, he is referred to as "Ka'na li Izz AL-Dawla" (means related to Izz AL-Dawla personally). After the murder of Khamma'r by the Turks in the continuous riots of Baghdad, Izz AL-Dawla asked for help form Deylami people for getting his revenge, but 
because of the dangerous situation and probability of conflict between Turks and Deylami people, he ignored this request (ibid, p. 348). In the same account, he adds that the employees of this Amir of Buyids were able in special situations to appoint someone to the position of Sahib Al-Shurta. For instance, in social and sect seditions of that time, Izz AL-Dawla appointed Saboktaki'n Ha'jib who was an efficient commander, for controlling the riots, and he appointed his own Ha'jib (confidant man) to the position of Khamma'r, who had been killed in the riots of Turks and he became the Sahib Al-Shurta of Baghdad (ibid).

However, in the following years, Buyids government encountered a number of problems in the realm of power in Iraq and Fars and due to a number of conflicts between the members of the grand family as well as the riots and domestic conflicts, and also their ignorance of the events of the other parts of the Islamic World, and consequently in facing the powerful and fresh forces of Seljuk governors, this dynasty declined. After dominance of Seljuks in Baghdad in 1055, the institution of Shurta became a part of the security institution of Shehneh. Since then, the institution of Shurta has been very rarely mentioned in the historical literatures.

\section{Conclusion}

The social context of Baghdad during Buyids period as well as abundance of criminal groups especially Ayyaran and evil groups resulted in a number of security and disciplinary challenges throughout the history of this city. From all challenges of this city, religious and sect conflicts should be considered as one of the most important problems of Baghdad especially during Buyids period.

Although the severe actions of Shurta in facing with the security disorders and criminals and employment of military forces for controlling the riots and conflicts were effective in reducing the problems, no one was the real solution and continuous insecure situation of Baghdad until emergence of Seljuks and their dominance on the capital city of Abbasids is an evidence which confirms this claim.

Table1. Terms appearing in the text with dialects

\begin{tabular}{lcl}
\hline Term Appearing in Text & Arabic & Term With Diacritics \\
\hline Shurta & شرطه & Shurta \\
Ayyarin & عياّرين & A'yyarin \\
Rub & اصحاب السكاكين & Rub' \\
Ashab Al-Sakakin & As'hab Al-Sakakin \\
\hline
\end{tabular}

\section{References}

Hamda'ni A. B. (1923). Maqa'ma't, Maktab Al-Azhar Val-M'ahed, Egypt. A Number of orientalist (1997), The Encyclopedia of Islam (Volume IX). Leiden Brill.

Ibn Al, J., Abu Al, F., Abd Al, R., \& Ibn Ali, I. M. (1992). Al- Muntadam Fi Ta'rikh Al-Omam Val Molu'k" research by:Mohammad Abd Al-Qa'der Ata and Mustafa Abd Al-Qa'der. Ata, Beirut, Dar Al-Kutub Al-ilmi'a, first edition.

Ibn Khaldu'n, \& Abd Al-Rahma'n Ibn, M. A. (1992). Al-Ibar va Divan Al-Mobtada' val-khabar" under supervision of Abu Suhaib Al-Karami', Beyt Al-Afka'r Al-Dowlia.

Ibn, K., \& Abul-feda' Isma'i'l Ibn Kathir A. (1979). Al -bedaya val-Nehaya. Beiru't, Da'r Al-Fikr, 1986.

Ibn, T., \& Ibn Ali Ibn Taba'taba', M. (1980). Al-Fakhri Fil Adab Al-Sulta'nia val-Dowal Al-Isla'mia. Dar Beirut Leltabaa val-Nashr.

Khatib Bagda'di, H. A. B. A. I. A. (1931). T'arikh Baghda'd", Egypt, Maktab al-Khanji of Cairo and Al-maktab Al-Arabiya of Bagdad.

Masu'di, Abul-Hasan Ali Ibn Husain Ibn Ali. (1409). Muruj Al-dhahab va Ma'adin Al-Jawhar (2nd ed.).

Muskovayh, A. A. (2000). Tajarib Al-umam (2nd ed.).

Qalqashandi, A. A. (1916). Subh Al-A 'sha" Matba-Al-Ami'ri'a of Cairo.

Tanu'khi, A. (1985). Al-Faraj Ba'd Al-Shidda, mans hu'ra't Al-shari'f Al-Radi Publications, Qom, second edition, Matba' Al-Amir. 
Tanu'khi, A. (1995). Nishvar Al-Muhadara Va Akhbar Al-Muzakara (2nd ed.). Research by Abbud Al-Shalji Al-Moha'mi, Da'r Al-Sa'dir, Beirut.

\section{Notes}

Note 1. Warrior and political agitator of the time of the caliph Uthman and supporter of Imam Ali.

Note 2. Literally, rascal, tramp, vagabond', Arabic pl. Ayyarin, Persian pl. Ayyaran

Note 3. The seventh Abbasid Caliph

Note 4. Prudence fear and also, from the root k-t-m, kitman, action of covering, dissimulation.

Note 5. Al-Mufid, Imami theologian and jurist, was born on 336/948.

Note 6. Imami theologian, grammarian, writer and poet, in short, an Arab adib, born and died in Baghdad (355-436/967-1044). 